\title{
Determinação dos alelos de grupos sanguíneos eritrocitários em pacientes politransfundidos do noroeste do Paraná, Sul do Brasil
}

\author{
Investigation of erythrocyte blood group alleles in multitransfused patients from the northwest of \\ Parana State, Southern Brazil
}

\author{
Gláucia Andréia Soares Guelsin \\ Orientador: Jeane Eliete Laguila Visentainer
}

\section{Resumo}

Antígenos de grupos sanguíneos são proteínas que estão ligadas a carboidratos ou a lipídeos e são expressas, principalmente, na superfície de hemácias. O conhecimento da variabilidade dos antígenos de grupos sanguíneos é essencial na prática transfusional, uma vez que o desenvolvimento de anticorpos contra esses antígenos pode levar a quadros hemolíticos graves, principalmente em casos de pacientes portadores de hemoglobinopatias ou outras doenças que requerem transfusões sanguíneas periódicas. A hemaglutimação clássica é a principal técnica utilizada na detecção dos diferentes grupos eritrocitrários. Contudo, ela apresenta limitações tornandose necessários outros protocolos para auxiliarem na detecção desses grupos. Alguns protocolos de genotipagem de grupos sanguíneos já estão bem estabelecidos e validados na população brasileira; contudo, torna-se ainda necessária a realização de estudos em diferentes regiões do Brasil. Nós avaliamos a utilidade da genotipagem de grupos sanguíneos como um suplemento à hemaglutinação para determinar o perfil de antígenos eritrocitários de pacientes politransfundidos com doenças hematológicas e falha renal. Setenta e nove pacientes foram selecionados, os quais receberam mais de 3 unidades de sangue e $8(10 \%)$ já tinham anticorpos clinicamente significantes, ocorrendo sozinhos, ou em combinação, contra antígenos Rh, K, Fya e Di. O DNA foi preparado de amostras de sangue e os alelos RHCE_E/e, KEL_01/KEL_02, FY_01/FY_02 e JK_01/JK_02 foram determinados por PCR-RFLיP. RHD_RHD_C e RHCE*C/c, sendo testados usando-se o PCR multiplex. As discrepâncias para os sistemas Rh, Kell, Duffy e Kidd foram encontradas entre os fenótipos e fenótipos derivados dos genótipos em 16 de 38 pacientes croni- camente transfundidos. Os genótipos desses pacientes foram confirmados por análises de DNA por microarray (HEA BeadchipTM; Bioarray Solutions, Warren, NJ). A genotipagem foi muito importante para a determinação dos verdadeiros grupos sanguíneos de pacientes politransfundidos, auxiliou na identificação de aloanticorpos suspeitos e na seleção de hemácias antígenonegativas para transfusão.

Descritores: Antígenos de grupos sanguíneos; Polimorfismo genético; Biologia molecular

\section{Abstract}

Red blood cell antigens are proteins linked to carbohydrates or lipids mainly expressed on the surface of red blood cells. Knowledge of red blood cell antigens is essential in transfusion medicine as the development of antibodies against these antigens may lead to severe hemolytic conditions especially in patients with hemoglobinopathies or other diseases that depend on frequent transfusions. The technique normally used to detect different erythrocytic groups is classical hemagglutination, however as this presents some limitations, additional tests are necessary. Some genotyping protocols are already defined and validated for the general Brazilian population but further studies are necessary in distinct Brazilian populations. We evaluated the usefulness of blood group genotyping as a complement to hemagglutination to determine the red blood cell antigen profile of multitransfused

Universidade Estadual de Maringá - UEM - Maringá (PR), Brasil.

Suporte financeiro: Laboratório de Imunogenética (LIG-UEM), CAPES, Fundação Araucária do Estado do Paraná.

Recebido: $15 / 11 / 2010$

Aceito: $21 / 11 / 2010$

Correspondência: Jeane Eliete Laguila Visentainer

Laboratório de Imunogenética/Departamento de Ciências Básicas da Saúde/Universidade Estadual de Maringá

Av. Colombo, 5790

87020-900 - Maringá (PR), Brasil

Fax: (55 44) 3011-4931; Tel: (55 44) 3011-4864

E-mail:jelvisentainer@uem.br; jelvisentainer@gmail.com 
patients with hematological diseases and renal failure. Seventynine patients that had received more than three units of blood were selected. Of these eight (10\%) already had one or more clinically significant alloantibodies against the Rh, K, Fya, and Di antigens. DNA was prepared from blood samples and the RHCE_E/e, KEL_01/KEL_02, FY_01/FY_02 and JK_01/JK_02 alleles were determined by polymerase chain reaction restriction fragment length polymorphism. RHD_RHD_C and $\mathrm{RHCE}^{*} \mathrm{C} / \mathrm{c}$ were tested using multiplex polymerase chain reaction. Discrepancies for Rh, Kell, Duffy, and Kidd systems were found between the phenotype and genotype derived phenotypes in 16 of 38 chronically transfused patients. The genotypes of these patients were confirmed by DNA array analysis (HEA Beadchip TM kit; Bioarray Solutions, Warren, $\mathrm{NJ})$. Genotyping was very important to determine the true blood groups of the multitransfused patients. It also helped in the identification of alloantibodies and in the selection of antigennegative red blood cells for transfusion.

Keywords: Blood group antigens; Polymorphism, genetic; Molecular biology

Avaliação: A RBHH publica os resumos e abstracts de teses da área apresentados em entidades que tenham programas de pós-graduação reconhecidos pelo MEC/Capes e considera a obtenção do título suficiente para sua publicação na forma como se propõe a seção. 